Research Article

\title{
Phytochemical and Antimicrobial Potential of the Roots of Berberis brevissima Jafri. (Berberidaceae)
}

\author{
Zain Ullah ${ }^{1 *}$, Anwar Ali Shad ${ }^{1}$ and Saqib Ali ${ }^{2}$
}

${ }^{1}$ Department of Agricultural Chemistry and Biochemistry, Faculty of Nutrition Sciences, The University of Agriculture Peshawar, Peshawar, Khyber Pakhtunkhwa, Pakistan; ${ }^{2}$ Department of Chemistry, University of Kotli, Azad Jammu E' Kashmir, Pakistan.

Abstract | Chemical screening on ethyl acetate fraction (Fr. C) obtained from the roots of Berberis brevissima Jafri. resulted in three compounds. Their structures were elucidated as $\beta$-Sitosterol-3- $O-\beta$-D-glucopyranoside (1), Berberine (2), and Pakistanine (3) using spectroscopic analysis, including mass, 1D, and 2D NMR data techniques. The antibacterial assays of the obtained six oil sub-fractions (H-1 to H-6) were accomplished against $S$. epidermis, E. coli, and $S$. aureus bacterial strains and the results ranged from 10-18 $\mathrm{mm}$ zone of inhibition. The GC-MS analysis of the six oil sub-fractions (H-1 to H-6) confirmed the existence of linoleic acid, palmitic acid, and oleic acid in the highest amount.

Received | November 30, 2019; Accepted | July 07, 2021; Published | September 13, 2021

*Correspondence | Zain Ullah, Department of Agricultural Chemistry and Biochemistry, Faculty of Nutrition Sciences, The University of Agriculture Peshawar, Peshawar, Khyber Pakhtunkhwa, Pakistan; Email: zainullah@posta.mu.edu.tr

Citation | Ullah Z., A.A. Shad and S. Ali. 2021. Phytochemical and antimicrobial potential of the roots of Berberis brevissima Jafri. (Berberidaceae). Sarhad Journal of Agriculture, 37(4): 1306-1313.

DOI | https://dx.doi.org/10.17582/journal.sja/2021/37.4.1306.1313

Keywords | Berberis brevissima, Ethyl acetate fraction, Antimicrobial potential, Fatty acids profile, Isolation, Structure elucidation

\section{Introduction}

$B$ erberis is the only genus of the family Berberidaceae, in the southerly hemisphere and comprises 600 species (Bai et al., 2011; Ali et al., 2020). About 24 species are widely distributed in Pakistan's mountainous parts, including Baluchistan, Gilgit, Chitral, Hazara, Murree, Swat, Dir, and Kashmir (Ali et al., 2020). The species is about 1-5 m tall, having deciduous and evergreen shrubs with yellow wood, thorny shoots, and simple leaves. Many species are distinguished for their attractive pink, violet, blue, or dark red color (Arayne et al., 2007). Various species of Berberis are generally dispersed in the temperate and semi-temperate region and are inherent of the whole range of the Himalayas Mountains and North America, Europe, Asia, and the Mediterranean regions (Knapp and Melly, 1986; Chevallier, 2011). The Spe- cies of the Berberis genus are famous for their traditional medicinal use. The evergreen shrub species with the intense pale-yellow color of shoots and roots are used for various ailments, such as rheumatism, stomach disorders diabetes, ear and eye infections, malarial fever, fever, skin disease, and jaundice in remote and rural areas (Ambastha, 1988; Watt, 1989; Whittemore, 1997; Janbaz and Gilani et al., 2000; Srivastava et al., 2006; Boon and Smith, 2009; Hassan et al., 2010; Godfrey et al., 2011). The extracts obtained from Berberis leaves were revealed to cure dysentery, scurvy, sore throat, angina, and have been used in modern drug preparations (Mokhber-Dezfuli et al., 2014; Ali et al., 2020).

Lately isolates from berberis species (berberine, sparteine, and scopolamine) have been employed for the allergic inflammation of the eye, the metabolic 
capacity of man and for the prevention of travel sickness, respectively (Souto et al., 2011). Berberine is an alkaloid present in roots, young shoots, leaves, flowers, fruits, and stems of all Berberis species and is available as medicine. The berberine content increases as the plant ages (Ali et al., 2015). Furthermore, berberine is a therapeutic alkaloid and has antidiabetic (Steriti, 2010), antidiarrheal (Issat et al., 2006), antitumor (Issat et al., 2006), anti-hyper cholesterol mia (Doggrell, 2005), anti-inflammatory (Kuo et al., 2004), and antipyretic (Küpeli et al., 2002) properties.

Assyrians used the fruits of Berberis as blood purifying agents (Karimov, 1993). The anticancer potential of $B$. aristata has been reported (Das et al., 2009). Various types of ulcers have been cured by using extracts obtained from the roots of $B$. asiatica, $B$. aristate, and B. lycium (Singh, 2007), also these extracts revealed antifungal activities.

B. brevissima locally is known as "ziar largy" and Barberry, found at Tirah (Khyber agency) in the northwest side of Pakistan. Roots, aerial parts, and especially the fruits are used for various medicinal and dietary purposes. The raw powdered and its crude extracts are used as tonic, astringent, and diaphoretic agents. The dietary uses include the fruit portion in the preparation of sauces, jellies, wines, and many other types of juices. It is also used as preservatives in many foods, and its pale-yellow color of roots and bark is an indigenous source of dye for female clothes. Recently many different products have been developed from B. brevissima, on a commercial scale (Kupeli et al., 2002). In Iran, this plant is used commonly in rice pilafs and as a flavoring agent for poultry meat. Their edible purple fruits are used for jams and infusions (Heywood and Chant, 1982). Research indicated that this plant is particularly active against cholera, giardia, shigella, salmonella, and E. coli (Chevallier, 2011).

Due to the advancement in spectroscopy (Nuclear magnetic resonance spectroscopy, mass spectroscopy, and X-Ray crystallography), elucidation and characterization of natural products have become much easier. Keeping the importance of native medicinal plants, the current study was conducted on the ethyl acetate fraction (Fr. C) of Berberis brevissima Jafri to investigate possible antibacterial and fatty acids profile of the n-hexane oil fractions using GC-MS, and purification of bioactive compounds.

\section{Materials and Methods}

\section{Plant materials collection and extraction}

The Berberis brevissima Jafri was collected on $25^{\text {th }}$ July 2010 from Tirrah (Khyber Agency). Identification of the plant was carried out with specimen \# Bot/10710 by plant taxonomist Prof. Dr. Jandar Shah, Benazir Bhutto University Sherengal Campus Upper Dir.

The dried and ground roots of Berberis brevissima Jafri $(5 \mathrm{Kg})$ were soaked in methanol for one week $(10 \mathrm{~L}$ $\mathrm{x} 7$ days). The crude extract (118.8 g) was collected in flasks and recovered using a rotary evaporator at 45 ${ }^{\circ} \mathrm{C}$ temperature.

\section{Fractionation and isolation}

The obtained $\mathrm{MeOH}$ crude extract (118.8 g) from the roots of $B$. brevissima was further fractionated for obtaining alkaloidal fraction through acidification and basification process. The water was acidified $(\mathrm{pH}=2)$ with the addition of $\mathrm{HCl}$. $\mathrm{pH}$ paper was used to adjust the $\mathrm{pH}$. In $1 \mathrm{~L}$ of this acidified water, the crude $\mathrm{MeOH}$ extract was dissolved. The undissolved residue was collected and named Fr. A (23.5 g). The remaining $\mathrm{H}_{2} \mathrm{O}$ soluble uniform mixture was shifted to a separating flask, and dichloromethane $(3 \times 500$ $\mathrm{mL}$ ) was added, shaken well, and allowed for the split of two layers. The dichloromethane layer was collected as Fr. B (21.8 g). Afterward the remaining homogenous water residue was basified with the addition of aqueous ammonia $(\mathrm{pH}=8)$ and obtained fraction Fr. $\mathrm{C}(27.4 \mathrm{~g})$ with the addition of ethyl acetate $(3 \times 500$ $\mathrm{mL})$. The remaining water residue was collected as Fr. $\mathrm{D}(46.1 \mathrm{~g})$.

The ethyl acetate fraction (Fr. C) was further processed through open gravity silica gel column chromatography (CC), and elution was carried out with $n$-hexane, chloroform, and methanol in a gradient manner. 57 sub-fractions were obtained from column chromatography (CC) based on TLC profile similarity. Sub-fraction Z-1 was further fractionated using CC and got six oil sub-fractions $(\mathrm{H}-1-\mathrm{H}-6)$. Sub-fraction Z-4 was further purified on a small Si-gel column, and compound 1 was isolated. Sub-fractions Z-42 and Z-46 were further purified through small columns and yielded compounds 2 and 3 , respectively.

\section{Preparation of methyl esters of fatty acids (FAMEs)}

The six oil sub-fractions were analyzed by GC-MS. $1.5 \mathrm{~mL}$ of $0.5 \mathrm{M}$ methanolic $\mathrm{NaOH}$ was added to 
the flask containing $25.0 \mathrm{mg}$ of the sample in a 25 $\mathrm{mL}$ volumetric flask and heated at $50{ }^{\circ} \mathrm{C}$ for five minutes in a water bath. After that, $1.5 \mathrm{~mL}$ of $\mathrm{BF}_{3}-$ $\mathrm{MeOH}$ was added and the mixture was heated at $80{ }^{\circ} \mathrm{C}$ for $5 \mathrm{~min}$. Then, a saturated $\mathrm{NaCl}$ solution $(2$ $\mathrm{mL}$ ) was added to the flask. Afterward, the sample mixture was moved to a separatory funnel, and added $5 \mathrm{~mL}$ of $\mathrm{n}$-hexane, shaken, and allowed for the separation of the aqueous and organic layers. The n-hexane layer (esterified layer) was removed and transferred into a $50 \mathrm{~mL}$ flask through filter paper. (Tokul-Olmez et al., 2018).

Fatty acids methyl esters analysis by $G C-M S$

For GC-MS analysis (QP 2010 plus-Shimadzu, Tokyo-Japan) of fatty acids, a capillary column (30 $\mathrm{m}, 0.35 \mathrm{~mm}, 0.250 \mu \mathrm{m}$ ) with $100 \mathrm{Pka}$ pressure was used. The initial temperature of the column was kept at $50{ }^{\circ} \mathrm{C}$ for one minute, then at the rate of $15{ }^{\circ} \mathrm{C} /$ min, raised to $150{ }^{\circ} \mathrm{C}$, then at the rate of $2.5^{\circ} \mathrm{C} / \mathrm{min}$, raised to $175^{\circ} \mathrm{C}$ for $5 \mathrm{~min}$, and finally raised to 220 ${ }^{\circ} \mathrm{C}$ for $5 \mathrm{~min}$, the total run time was $45 \mathrm{~min}$. Interface and ion source temperatures were $240{ }^{\circ} \mathrm{C}$ and $250{ }^{\circ} \mathrm{C}$, respectively. The sample $(1 \mu \mathrm{L})$ was inserted at $240{ }^{\circ} \mathrm{C}$. Helium was used as a sample carrier.

EI-MS were taken at ionization energy of $70 \mathrm{eV}$, with the mass scanning range from $\mathrm{m} / \mathrm{z} 85$ to $\mathrm{m} / \mathrm{z}$ 380 amu. NIST (NIST 05) library was used for compounds identification.

\section{Antibacterial assay}

The antibacterial potential of the oil sub-fractions (H-1 to H-6) was carried out through the Agar Well Diffusion assay. At $37{ }^{\circ} \mathrm{C}$ the prepared cultures were incubated for $24-72$ hours. $0.2 \mathrm{~mL}$ of all samples were placed in the holes and $2 \mathrm{mg} / \mathrm{mL}$ of Streptomycin was used as standard. The samples were then incubated at $37^{\circ} \mathrm{C}$ for 24 hours and the inhibition zones were determined in millimeters (Alamzeb et al., 2013).

\section{Nuclear magnetic resonance spectroscopy (NMR)}

${ }^{1} \mathrm{H}-$ and ${ }^{13} \mathrm{C}-\mathrm{NMR}$ spectra were acquired using deuterated solvents $\left(\mathrm{MeOD}, \mathrm{DMSO}\right.$, and $\mathrm{CDCl}_{3}$ ) on a Bruker 400-NMR. Various types of NMR procedures (BB, DEPT-90, DEPT-135, HSQC, COSY, and $\mathrm{HMBC}$ ) were employed for structure identification.

\section{Mass spectroscopy}

Using glycerol as standard matrix and xenon as gas, mass spectra (JEOL MS Route resolution, and JEOL
JMS HX 110 mass spectrometer) were obtained at Husein Ebrahim Jamal research institute of Chemistry, University of Karachi, Pakistan.

Thin-layer chromatography (TLC)

$20 \times 20 \mathrm{~cm}$ aluminum sheets precoated with silica gel $\left(60 \mathrm{~F}_{254}\right)$ were used. The developed TLC plates were spotted under UV (ultraviolet). Various reagents (Dragent Draft and Cerric Sulphate) were employed for detecting compound nature.

\section{Results and Discussion}

The investigation on B. brevissima roots ethyl acetate fraction (Frac. C) revealed three known (1-3) compounds. The known compounds were identified as $\beta$-sitosterol-3- $O$ - $\beta$-D-glucopyranoside (1) (Sabira et al., 2000; Lingamallu et al., 2002), berberine (2) (Shamma et al., 1972; Shamma and Rahimizadeh, 1986), and pakistanine (3) (Shamma and Rahimizadeh, 1986; Shamma et al., 1972). The oil sub-fractions were analyzed through GC-MS and further evaluated for their antimicrobial activities against three bacterial strains.

\section{$G C-M S$ analysis results}

The GC-MS results of six oil sub-fractions (H-1 H-6) obtained from B. brevissima were given in Table 1. Linoleic acid was found at the highest concentration (48.34 \% and $16.21 \%$ ) in $\mathrm{H}-2$ and $\mathrm{H}-4$ sub-fractions respectively, palmitic acid was found in the highest concentration (14.77 \% and $6.31 \%$ ) in sub-fractions $\mathrm{H}-1$ and $\mathrm{H}-2$ respectively, and oleic acid was found in good amount in sub-fraction H-2 (3.46 \%), whereas the results also confirmed the samples as a moderate source of capric acid, myristic acid, margaric acid, pentadecanoic acid, behenic acid, elaidic acid, palmitoleic acid, and tridecanoic acid.

\section{Antibacterial activity results}

The antibacterial activity of the oil sub-fractions (H-1-H-6) was investigated against Escherichia coli, Staphylococcus epidermis, and Staphylococcus aureus. The results (Table 2) revealed that the $\mathrm{H}-1$ exhibited good activity against $E$. coli with a zone of inhibition of 10 $\mathrm{mm}$. The $\mathrm{H}-2$ showed noteworthy activity against $E$. coli $(14 \mathrm{~mm})$, while modest activity against $S$. aureus (10 mm). The H-3 exhibited activity against $S$. epidermis $(11 \mathrm{~mm})$, and $E$. coli $(10 \mathrm{~mm})$ respectively. The H-5 demonstrated the same results against E. coli and $S$. aureus $(12 \mathrm{~mm})$. The H-6 exhibited good results 
Table 1: Fatty acids analysis (\%) of the oil sub-fractions obtained from the roots of B. brevissima.

\begin{tabular}{|c|c|c|c|c|c|c|c|c|}
\hline Fatty acid & Formula & Mass & H-1 & H-2 & H-3 & $\mathrm{H}-4$ & H-5 & H-6 \\
\hline Arachidic acid, methyl ester & $\mathrm{C}_{20} \mathrm{H}_{40} \mathrm{O}_{2}$ & 312.5 & 0.19 & - & - & - & - & - \\
\hline Behenic acid, methyl ester & $\mathrm{C}_{22} \mathrm{H}_{44} \mathrm{O}_{2}$ & 340.5 & 0.18 & 0.05 & - & - & - & - \\
\hline Capric acid, methyl ester & $\mathrm{C}_{10} \mathrm{H}_{20} \mathrm{O}_{2}$ & 172.2 & - & 0.04 & 0.01 & 0.03 & - & 0.01 \\
\hline Caprylic acid, methyl ester & $\mathrm{C}_{8} \mathrm{H}_{16} \mathrm{O}_{2}$ & 144.2 & - & 0.02 & 0.01 & 0.02 & 0.01 & 0.01 \\
\hline Elaidic acid, methyl ester & $\mathrm{C}_{18} \mathrm{H}_{34} \mathrm{O}_{2}$ & 282.4 & - & 0.80 & 0.02 & 0.08 & 0.02 & 0.04 \\
\hline Heneicosanoic acid, methyl ester & $\mathrm{C}_{21} \mathrm{H}_{42} \mathrm{O}_{2}$ & 326.5 & 0.02 & - & - & - & - & - \\
\hline Hexanoic acid, methyl ester & $\mathrm{C}_{6} \mathrm{H}_{12} \mathrm{O}_{2}$ & 116.1 & - & 0.09 & 0.17 & 0.12 & 0.15 & - \\
\hline Heptadecenoic acid, methyl ester & $\mathrm{C}_{17} \mathrm{H}_{34} \mathrm{O}_{2}$ & 270.4 & - & 0.25 & - & - & - & - \\
\hline Lauric acid, methyl ester & $\mathrm{C}_{12} \mathrm{H}_{24} \mathrm{O}_{2}$ & 200.3 & 0.03 & 0.08 & 0.01 & 0.04 & 0.01 & 0.03 \\
\hline Linoleic acid, methyl ester & $\mathrm{C}_{18} \mathrm{H}_{32} \mathrm{O}_{2}$ & 280.4 & - & 48.34 & 1.55 & 16.21 & 1.35 & 2.99 \\
\hline Margaric acid, methyl ester & $\mathrm{C}_{17} \mathrm{H}_{34} \mathrm{O}_{2}$ & 270.4 & 0.76 & 0.21 & 0.02 & 0.04 & 0.01 & 0.02 \\
\hline Myristic acid, methyl ester & $\mathrm{C}_{14} \mathrm{H}_{28} \mathrm{O}_{2}$ & 228.3 & 0.15 & 0.14 & 0.02 & 0.05 & 0.01 & 0.05 \\
\hline Oleic acid, methyl ester & $\mathrm{C}_{18} \mathrm{H}_{34} \mathrm{O}_{2}$ & 282.4 & - & 3.46 & 0.18 & 0.44 & 0.10 & 0.25 \\
\hline Palmitic acid, methyl ester & $\mathrm{C}_{16} \mathrm{H}_{32} \mathrm{O}_{2}$ & 256.4 & 14.77 & 6.31 & 0.55 & 1.40 & 0.40 & 0.64 \\
\hline Palmitoleic acid, methyl ester & $\mathrm{C}_{16} \mathrm{H}_{30} \mathrm{O}_{2}$ & 254.4 & - & 0.12 & - & 0.11 & - & - \\
\hline Pentadecanoic acid, methyl ester & $\mathrm{C}_{15} \mathrm{H}_{30} \mathrm{O}_{2}$ & 242.4 & 0.30 & 0.17 & 0.01 & 0.04 & 0.01 & 0.02 \\
\hline Stearic acid, methyl ester & $\mathrm{C}_{18} \mathrm{H}_{36} \mathrm{O}_{2}$ & 284.4 & 0.87 & 0.20 & 0.05 & 0.05 & 0.03 & 0.14 \\
\hline Tetracosanoic acid, methyl ester & $\mathrm{C}_{24} \mathrm{H}_{48} \mathrm{O}_{2}$ & 368.6 & 0.04 & - & - & - & - & - \\
\hline Tricosanoic acid, methyl ester & $\mathrm{C}_{23} \mathrm{H}_{46} \mathrm{O}_{2}$ & 354.6 & - & - & - & - & - & 0.01 \\
\hline Tridecanoic acid, methyl ester & $\mathrm{C}_{13} \mathrm{H}_{26} \mathrm{O}_{2}$ & 214.3 & - & 0.01 & 0.11 & - & - & - \\
\hline Undecanoic acid, methyl ester & $\mathrm{C}_{11} \mathrm{H}_{22} \mathrm{O}_{2}$ & 186.3 & - & 0.01 & - & 0.01 & 0.01 & - \\
\hline
\end{tabular}

Table 2: Anti-microbial activities of the oil sub-fractions obtained from the roots of $B$. brevissima.

$\begin{array}{llll}\text { Zone of Inhibition } & (\mathbf{m m}) & & \\ \text { Oil fracions } & \text { E. coli } & \text { S. epidermis } & \text { S. aureus } \\ \text { H-1 } & 10 & - & - \\ \text { H-2 } & 14 & - & 08 \\ \text { H-3 } & 10 & 11 & - \\ \text { H-4 } & - & - & - \\ \text { H-5 } & 12 & - & 12 \\ \text { H-6 } & 14 & 16 & - \\ \text { Streptomycin } & 28 & 32 & 28\end{array}$

against S. epidermis and E. coli (16 and $14 \mathrm{~mm})$. However, none of the sub-fractions showed as good results as the Streptomycin standard.

\section{Structure elucidation of the isolated compounds}

Compound 1: Molecular ion peak at $\mathrm{m} / \mathrm{z} 576.43$ in FAB-MS, suggested a molecule formula of $\mathrm{C}_{12} \mathrm{H}_{22} \mathrm{O}_{11}{ }^{+}$, (calcd. $\mathrm{C}_{35} \mathrm{H}_{50} \mathrm{O}, 576.43$ ). The ${ }^{13} \mathrm{C}-\mathrm{NMR}$ spectrum exposed 35 carbons (6 methyls, 12 methylenes, 14 methines, and 3 quaternary carbons). The aglycone part gives distinctive signals at $\delta_{C} 140.4$, 121.1, 76.7, 56.1, 55.4, 49.6, 45.1, 41.8, 39.2, 38.3,
$36.8,36.2,35.4,33.3,31.4,31.3,29.2,28.7,27.7,25.4$, $23.8,22.7,20.5,19.6,19.0,19.0,18.6,11.7$, and 11.6. The aglycone part was verified to be $\beta$-sitosterol by evaluating ${ }^{13} \mathrm{C}-\mathrm{NMR}$ data for $\beta$-sitosterol (Lingamallu et al., 2002; Sabira et al., 2000).

The ${ }^{1} \mathrm{H}-\mathrm{NMR}$ spectra $\left(\mathrm{C}_{5} \mathrm{D}_{5} \mathrm{~N}\right)$ of the compound 1 , confirmed the existence of two peaks at $\delta_{H} 0.64(3 \mathrm{H}$, $s, \mathrm{H}-18)$ and $0.94(3 \mathrm{H}, s, \mathrm{H}-19)$ for 2 methyl groups, the signals at $\delta_{H} 0.89(3 \mathrm{H}, d, J=6.4 \mathrm{~Hz}, \mathrm{H}-21), 0.80$, $(3 \mathrm{H}, d, J=7.3 \mathrm{~Hz}, \mathrm{H}-27)$, and $0.82(3 \mathrm{H}, d, J=7.2 \mathrm{~Hz}$, $\mathrm{H}-26)$ indicated 3 doublets methyls. The resonance at $\delta_{H} 0.77(3 \mathrm{H}, t, J=6.9 \mathrm{~Hz}, \mathrm{H}-29)$ indicated 1 methyl triplets, the peaks at $\delta_{H} 5.29(1 \mathrm{H}, m, \mathrm{H}-6)$, indicated the presence of an olefinic proton broad multiplet. The signals at $\delta_{H} 3.45(1 \mathrm{H}, m, \mathrm{H}-3)$ indicated the presence of a multiplet. The ${ }^{1} \mathrm{H}-\mathrm{NMR}$ of compound 1 exposed the presence of the sugar part, resonated at $\delta_{H} 4.20\left(1 \mathrm{H}, d, J=7.5 \mathrm{~Hz}, \mathrm{H}-1^{\prime}\right), 3.62(2 \mathrm{H}, d d, J$ $\left.=4.5,10.9 \mathrm{~Hz}, \mathrm{H}-6^{\prime}\right), 3.11\left(1 \mathrm{H}, m, \mathrm{H}-3^{\prime}\right), 3.04(1 \mathrm{H}$, $\left.m, \mathrm{H}-4^{\prime}\right), 2.88\left(1 \mathrm{H}, m, \mathrm{H}-2^{\prime}\right)$, and $3.08\left(1 \mathrm{H}, m, \mathrm{H}-5^{\prime}\right)$. The signals in ${ }^{1} \mathrm{H}$-and ${ }^{13} \mathrm{C}-\mathrm{NMR}$ spectra also indicated the sugar part as glucose. From the above spectral data, and by assessment with the literature, the structure of compound 1 was predicted as $\beta$-sitoster- 
ol-3-O- $\beta$-D-glucopyranoside (Figure 1) (Sabira et al., 2000; Lingamallu et al., 2002).
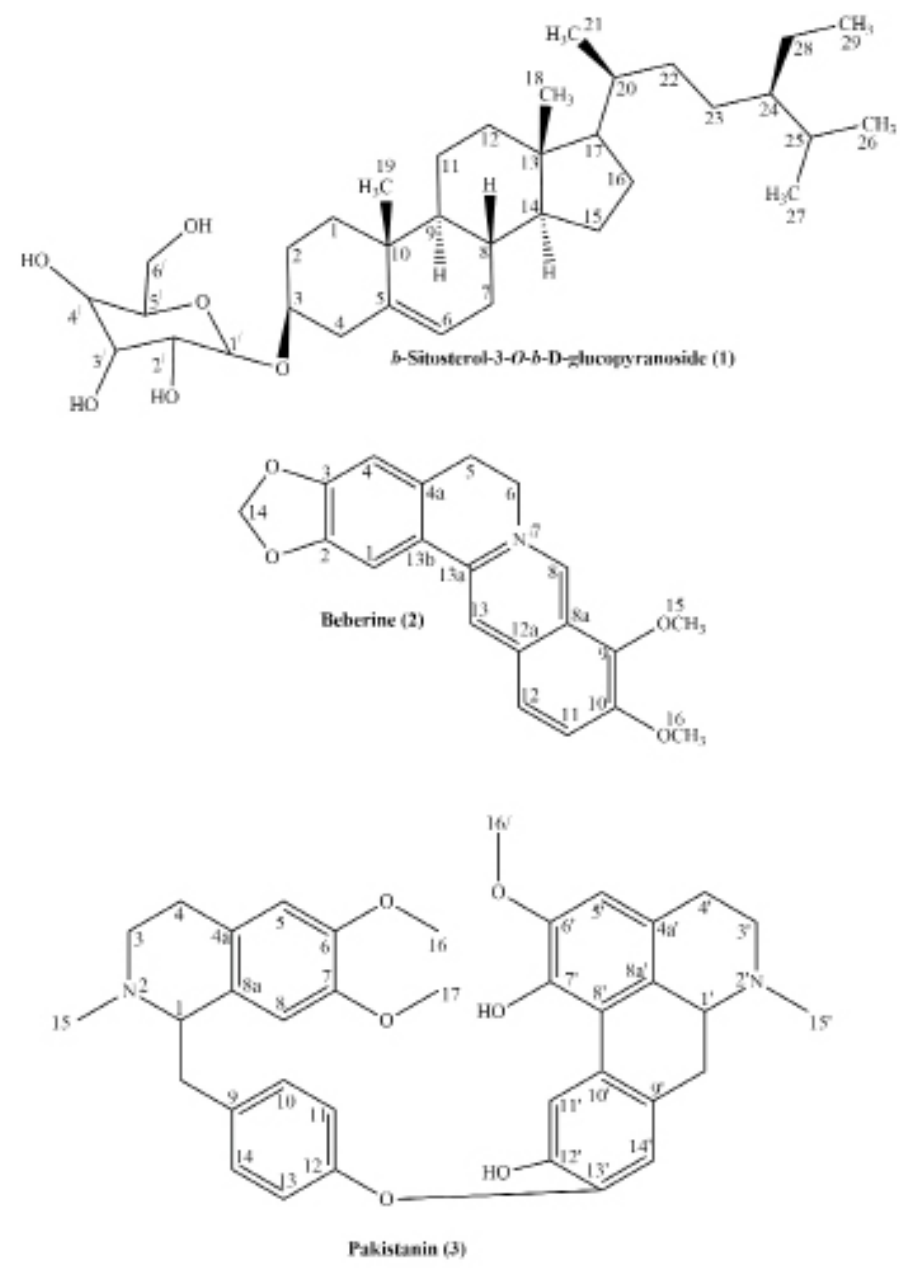

Figure 1: Structure of compounds 1-3.

Compound 2: The molecule formula of compound 2 was suggested to be $\mathrm{C}_{20} \mathrm{H}_{18} \mathrm{~N}^{+} \mathrm{O}_{4}$ based on the EIMS molecular ion peak at $\mathrm{m} / z 336$ (calcd. 336 for $\mathrm{C}_{20} \mathrm{H}_{18} \mathrm{~N}^{+} \mathrm{O}_{4}$ ). The ${ }^{13} \mathrm{C}-\mathrm{NMR}$ spectrum displayed twenty signals for 2 methyls, 3 methylenes, 6 methines, and 9 quaternary carbons. The distinctive signals at $\delta_{C} 150.3,149.9,148.9,147.7,147.7,146.4$, 144.0, 137.5, 130.6, 128.2, 124.5, 120.2, 109.4, 106.5, 103.7, 61.9, 57.7, 55.3, and 28.21 were detected.

The compound $2{ }^{1} \mathrm{H}-\mathrm{NMR}$ spectra resonated at $\delta_{H}$ $4.10(3 \mathrm{H}, s, \mathrm{H}-16)$, and $4.20(3 \mathrm{H}, s, \mathrm{H}-15)$ indicated two methyl singlets, the singlet at $\delta_{H} 6.10(2 \mathrm{H}, s$, $\mathrm{H}-14)$ indicated one methylene, the peaks at $\delta_{H} 4.91$ $(2 \mathrm{H}, t, J=6.5 \mathrm{~Hz}, \mathrm{H}-5)$, and $3.43(2 \mathrm{H}, t, J=6.5 \mathrm{~Hz}$, $\mathrm{H}-6)$, showed Two methylene triplets, the peaks observed at $\delta_{H} 7.65(1 \mathrm{H}, s, \mathrm{H}-4), 6.94(1 \mathrm{H}, s, \mathrm{H}-1), 8.71$ $(1 \mathrm{H}, s, \mathrm{H}-13)$, and $9.75(1 \mathrm{H}, s, \mathrm{H}-8)$ confirmed the presence of four methines, and the singlets at $\delta_{H} 8.11$ $(1 \mathrm{H}, d, J=9.6 \mathrm{~Hz}, \mathrm{H}-12)$, and $8.13(1 \mathrm{H}, d, J=9.6$ $\mathrm{Hz}, \mathrm{H}-11)$ indicated two methine doublets. From the mass and NMR spectra, and the data collected from literature, the compound (2) was elucidated as Berberine (Figure 1) (Shamma et al., 1973; Shamma and Rahimizadeh, 1986).

Compound 3: The molecule formula of compound 3 was suggested to be $\mathrm{C}_{37} \mathrm{H}_{40} \mathrm{~N}_{2} \mathrm{O}_{6}{ }^{+}$based on the EIMS molecular ion peak at $\mathrm{m} / z 608$ (calcd. 608 for $\mathrm{C}_{37} \mathrm{H}_{40} \mathrm{~N}_{2} \mathrm{O}_{6}$ ). The broadband ${ }^{13} \mathrm{C}-\mathrm{NMR}$ spectra indicated thirty-seven peaks containing five methyls, six methylenes, eleven methines, and fifteen quaternary carbons. The peaks at $\delta_{C} 153.64,147.39,147.35$, $146.90,143.52,143.13,131.60,128.88,127.92$, $127.91,124.34,121.75,121.35,118.76,114.47$, $113.99,111.18,110.92,63.98,61.14,60.53,55.98$, $54.92,46.24,46.04,42.83,38.62,37.54$, and 25.60 were observed.

The ${ }^{1} \mathrm{H}-\mathrm{NMR}$ spectra of the compound 3, the signals at $\delta_{H} 2.23\left(3 \mathrm{H}, s, \mathrm{H}-15,15^{\prime}\right), 3.09\left(3 \mathrm{H}, s, \mathrm{H}-16^{\prime}\right)$, $3.12(3 \mathrm{H}, s, \mathrm{H}-16)$, and $3.72(3 \mathrm{H}, s, \mathrm{H}-17)$, indicated five methyl singlets, the resonance at $\delta_{H} 2.76(2 \mathrm{H}$, $\left.m, \mathrm{H}-3,3^{\prime}\right), 2.81$ (2H, m, H-4), 2.79 (2H, m, H-4'), $2.90\left(2 \mathrm{H}, m, \mathrm{H}-\alpha^{\prime}\right)$, and $2.91(2 \mathrm{H}, m, \mathrm{H}-\alpha)$ indicated six methylene multiplets, the peaks at $\delta_{H} 6.94(1 \mathrm{H}, s$, $\mathrm{H}-5), 6.96(1 \mathrm{H}, s, \mathrm{H}-8), 6.78\left(1 \mathrm{H}, s, \mathrm{H}-5^{\prime}\right), 7.0(1 \mathrm{H}$, $\left.s, \mathrm{H}-10^{\prime}\right)$, and $7.08\left(1 \mathrm{H}, s, \mathrm{H}-13^{\prime}\right)$ were observed five methine singlets, the signals at $\delta_{H} 7.26(1 \mathrm{H}, d, J=8.1$ $\mathrm{Hz}, \mathrm{H}-10,14)$, and 7.42 (1H, d, $J=8.1 \mathrm{~Hz}, \mathrm{H}-11$, 13) showed four methine doublets and the resonance at $\delta_{H} 4.18(1 \mathrm{H}, b r . s, \mathrm{H}-1)$, and $4.17\left(1 \mathrm{H}, b r . s, \mathrm{H}-1^{\prime}\right)$ indicated two methine broad singlets. The obtained mass, NMR spectral data and the data obtained from literature, the structure of compound 3 was elucidated as pakistanine (Figure 1) (Shamma et al., 1972; Shamma et al., 1973).

\section{Conclusions and Recommendations}

The fatty acid analysis results of the oils were consistent with the reported ones (Nergiz and Donmez, 2004; Nasri et al., 2005; Koksal et al., 2006). From the current study, it was concluded that the oil sub-fractions of B. brevissima are decent source of fatty acids and are a potential source of antimicrobial agents. Phytochemical investigation on Berberis brevissima Jafri revealed two isoquinoline alkaloids named berberine (2) and pakistanine (3). Research on Berberis species has revealed that alkaloids have anti-microbiocidal properties (Ghoshal et al., 1996). Berberine is the major constituent of the Berberis spp. along with 
other principal isoquinoline alkaloids (Freile et al., 2003; Ali et al., 2013). Berberine was reported to be the principal antibacterial and antifungal component of the Berberis genus. and is significantly active against S. aureus and Candida spp (Aydemir and Biloglu, 2003; Ali et al., 2013). Berberine has been found effective against many trypanosomes (Ali et al.,2018) and many invertebrate pests (Rattan, 2010).

The current study confirmed the importance of Berberis brevissima Jafri due to the presence of these bioactive components which were already reported from other Berberis species. It is recommended that the current studied plant desires more study for further bioactive components and valued nutraceuticals.

\section{Acknowledgments}

The authors are indebted to the Department of Agricultural Chemistry and Biochemistry, Faculty of Nutrition Sciences, The University of Agriculture Peshawar for providing financial support and necessary laboratory facilities.

\section{Novelty Statement}

The Ethyl acetate fraction obtained from the roots of Berberis brevissima Jafri were investigated phytochemically, Fatty acids profile was studied using GCMS, and antibacterial potential of the obtained oils were also studied.

\section{Author's Contribution}

Zain Ullah: Conducted the research.

Anwar Ali Shad: Designed and supervised the whole research work.

Saqib Ali: Co-supervised the lab work.

\section{Conflict of interest}

The authors have declared no conflict of interest.

\section{References}

Alamzeb, M., M.R. Khan, S, Ali, S.Q. Shah and M.U. Rashid. 2013. Antimicrobial properties of extracts and compounds isolated from Berberis jaeschkeana. Bangladesh J. Pharmacol. 8 (2): 107-109. https://doi.org/10.3329/bjp. v8i2.13551

Ali, H., S. Uddin and S. Jalal. 2015. Chemistry and biological activities of berberis lycium Royle. J. Biol. Active Prod. Nat. 5(5): 295-312. https:// doi.org/10.1080/22311866.2015.1073627

Ali, S., I. Naz, M. Alamzeb and M. Rashid. 2018. Activity Guided Isolation of nematicidal constituents from the roots of Berberis brevissima Jafri and Berberis parkeriana Schneid. J. Agric. Sci. 25 (2019): 108-114. https://doi. org/10.15832/ankutbd.539012

Ali, S., J. Igoli., C. Clements., D. Semaan., M. Alamzeb., M. Rashid., S.Q. Shah., V.A. Ferro., A.I. Gray and M.R. Khan. 2013. Antidiabetic and antimicrobial activities of fractions and compounds isolated from Berberis brevissima Jafri and Berberis parkeriana Schneid. Bangladesh J. Pharmacol. 8: 336-342. https://doi. org/10.3329/bjp.v8i3.13888

Ali, S., M. Alamzeb, M. Rashid and W.N. Setzer 2020. Effect of Temperature on ${ }^{1} \mathrm{H}$ NMR Spectra, Antitrypanosomal Activity, Conformational Analysis, and Molecular Docking of Curine Derivatives from Berberis brevissima. J. Nat. Prod. 83 (5): 1383-1393. https://doi. org/10.1021/acs.jnatprod.9b00397

Ambastha S.P. 1988. The Wealth of India. Publication and information directorate: Council for Scientific and Industrial Research (CSIR). New Dehli. India. 2B: 118.

Arayne, M.S., N. Sultana and S.S. Bahadur. 2007. The Berberis story: Berberis vulgaris in therapeutics. Pak. J. Pharm. Sci. 20(1): 83-92.

Aydemir, N. and R. Bilaloglu. 2003. Genotoxicity of two anticancer drugs, gemcitabine, and topotecan, in mouse bone marrow in vivo. Mutat. Res. 537(1): 43-51. https://doi.org/10.1016/ S1383-5718(03)00049-4

Bai, C.Q. Z.L. Liu and Q.Z. Liu. 2011. Nematicidal constituents from the essential oil of Chenopodium ambrosioides aerial parts. E-J. Chem. 8(S1): S143-S148. https://doi. org/10.1155/2011/470862

Boon, H. and M. Smith. 2009. Most Common medicinal herbs: The Complete natural medicine guide second edition institute of naturopathic education and research, CCNM Toronto.

Chevallier, A. 2011. Encyclopedia of Medicinal Plants. Revised Edition. Sydney, Australia: Dorling Kindersley.

Das, S., M.K. Das, P.M. Mazumder, S. Das and S.P. Basu. 2009. Cytotoxic Activity of Methanolic Extract of Berberis aristata DC on Colon Can- 
cer. Global J. Pharmacol. 3(3): 137-140.

Doggrell, S. 2005. Berberine-a novel approach to cholesterol-lowering. Expert Opin. Invest. Drugs. 14(5): 683-685. https://doi. org/10.1517/13543784.14.5.683

Freile,M.L.,F.Giannini., G.Pucci.,A. Sturniolo.,L. Rodero., O. Pucci., V. Balzareti and R.D. Enriz. 2003. Antimicrobial activity of aqueous extracts and of berberine isolated from Berberis heterophylla. Fitoterapia. 74(7-8): 702-705. https:// doi.org/10.1016/S0367-326X(03)00156-4

Ghoshal, S., B.N. Krishna and V. Lakshmi. 1996. Antiamoebic activity of Piper longum fruits against Entamoeba bistolytica in-vitro and in-vivo. J. Ethnopharmacol. 50(3): 167-170. https:// doi.org/10.1016/0378-8741(96)01382-7

Godfrey, A., P. Saunders, K. Barlow and M. Gowan. 2011. Principles and Practices of Naturopathic Botanical Medicine. Adv. Botanic. Med. V3 CCNM Press. Toronto.

Hassan, S., A.Y. Mohammad and H. Sher. 2010. Forest resource utilization assessment for economic development of rural community in northern parts of Pakistan. J. Med. Plants Res. 4(12): 1197-1208.

Heywood, V.H. and S.R. Chant. 1982. Popular encyclopedia of plants. Cambridge University Press. Cambridge.

Issat, T., M. Jakóbisiak and J. Golab. 2006. Berberine, a natural cholesterol reducing product, exerts antitumor cytostatic/cytotoxic effects independently from the mevalonate pathway. Onco Rep. 16(6): 1273- 1276. https://doi. org/10.3892/or.16.6.1273

Janbaz, K.H. and A.H. Gilani. 2000. Studies on preventive and curative effect of Berbarine in hepatotoxic rodents. Fitoterapia. 71(1): 25-33. https://doi.org/10.1016/S0367326X(99)00098-2

Karimov, A. 1993. Berberis alkaloids. Chem. Nat. Comp. 29(4): 415-438. https://doi. org/10.1007/BF00630564

Knapp, H.R. and M.A. Melly. 1986. Bactericidal effects of polyunsaturated fatty acids. J. Infec. Dis. 154(1): 84-94. https://doi.org/10.1093/ infdis/154.1.84

Koksal, A.I., N. Artik, A. Simsek and N, Gunes. 2006. Nutrient composition of hazelnut ( $\mathrm{Co}-$ rylus avellana L.) varieties cultivated in Turkey. Food Chem. 99(3): 509-515. https://doi. org/10.1016/j.foodchem.2005.08.013
Kuo, C., C. Chi and T. Liu. 2004. The anti-inflammatory potential of berberine in vitro and in vivo. Cancer Letters. 203(2): 127-137. https:// doi.org/10.1016/j.canlet.2003.09.002

Kupeli, E., M. Kosar, E.K. Yesilada, K.H.C. Baser and C.A. Baser. 2002. A Comparative study on the anti-inflammatory, antinociceptive and antipyretic effects of isoquinoline alkaloids from the roots of Turkish Berberis species. Life Sci. 72(6): 645-657. https://doi.org/10.1016/ S0024-3205(02)02200-2

Küpeli, E., M. Koşar., E. Yeşilda., K. Husnu and K. Başer. 2002. A comparative study on the anti-inflammatory, antinociceptive and antipyretic effects of isoquinoline alkaloids from the roots of Turkish Berberis species. Life Sci. 72(6): 645-657. https://doi.org/10.1016/S00243205(02)02200-2

Lingamallu, J.M.R., H. Yada, H. Ono and M. Yoshida. 2002. Acylated and Non-Acylated Flavonol Monoglycosides from the Indian Minor Spice Nagkesar (Mammea longifolia). J. Agric. Food Chem. 50(11): 3143-3146. https:// doi.org/10.1021/jf011461m

Mokhber-Dezfuli, N., S. Saeidnia, A.R. Gohari and M. Kurepaz-Mahmoodabadi. 2014. Phytochemistry and pharmacology of berberis species. Pharma. Rev. 8(15): 8-15.

Nasri, N., A. Khaldi, B. Fady and S. Triki.2005. Fatty acid from seeds of Pinus pinea L.: Composition and population profiling. Phytochemistry. 66(14): 1729-1735. https://doi.org/10.1016/j. phytochem.2005.05.023

Nergiz, C. and I. Donmez. 2004. Chemical composition and nutritional value of Pinus pinea $\mathrm{L}$. seeds. Food Chem. 86(3): 365-368. https://doi. org/10.1016/j.foodchem.2003.09.009

Rattan, R.S. 2010. Mechanism of action of insecticidal secondary metabolites of plant origin. Crop Prot. 29(9): 913-920. https://doi. org/10.1016/j.cropro.2010.05.008

Sabira, B., I. Farhat, B.S. Sultana, F. Siddiqui, A. Shaheen and H. Gilani. 2000. Spasmolytic Constituents from Eucalyptus camaldulensis var. obtusa Leaves. J. Nat. Prod. 63(9): 1265-1268. https://doi.org/10.1021/np9902340

Shamma, M. 1972. The isoquinoline alkaloids. $A c a-$ demic Press: New York., 521.

Shamma, M. and M. Rahimizadeh. 1986. The identity of chileninone with berberrubine. The Problem of true natural products vs. artifacts of 
isolation. J. Nat. Prod., 49(3): 398-405. https:// doi.org/10.1021/np50045a003

Shamma, M., J.L. Moniot, S.Y. Yao, G.A. Miana and M. Ikram. 1972. Pakistanine and Pakistanamine, two novels dimeric isoquinoline alkaloids. J. Am. Chem. Soc. 94(4): 1381-1382. https://doi.org/10.1021/ja00759a071

Singh, M., S. Srivastava and A.K.S. Rawat. 2007. Antimicrobial activities of indian Berberis species. Fitoterapia. 78: 574-576. https://doi. org/10.1016/j.fitote.2007.03.021

Shamma, M., J.L. Moniot, Y. Yao, G.A. Miana and M. Ikram. 1973. Pakistanine and Pakistanamine, two new dimeric isoquinoline alkaloids. J. Americ. Chem. Soc. 95 (17): 5742-5747.

Souto, A.L., J.F. Tavares, M.S. da Silva, M.de Fátim, P. F. de Athayde-Filho and J.M.B. Filho. 2011. Anti-inflammatory activity of alkaloids. Molecules. 16: 8515-8534. https://doi.org/10.3390/ molecules16108515
Srivastava, S.K., V. Rai, M. Srivastava, A, Rawat and S. Mehrotra. 2006. Estimation of heavy metals in different Berberis species and its market samples. Environ. Monit. Assess., 116(1-3): 315-320. https://doi.org/10.1007/s10661-0067395-x

Steriti, R. 2010. Berberine for diabetes mellitus type 2. Nat. Med. J. 2(10): 5-6.

Tokul-Olmez, O., E. Kaplaner, M. Ozturk, Z. U1lah and M.E. Duru. 2018. Fatty acid profile of four Ganoderma species collected from various host trees with chemometric approach. Biochem. Systemat. Ecol. 78(2018): 91-97. https:// doi.org/10.1016/j.bse.2018.03.008

Watt, G. 1889. A dictionary of the economic products of India; Secretary of State for India in Council: Kolkatta, London. p. 652.

Whittemore, A.T. 1997. Berberis Linnaeus. Flora of North America Editorial. 3: 276-286. 